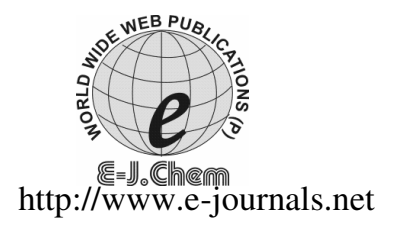

ISSN: 0973-4945; CODEN ECJHAO

E-Journal of Chemistry

2011, 8(4), 1582-1587

\title{
Glyphosate Utilization as the Source of Carbon: Isolation and Identification of new Bacteria
}

\author{
M. MOHSEN NOUROUZI ${ }^{\S^{*}}$, T.G. CHUAH ${ }^{\S}$, \\ THOMAS S.Y. CHOONG ${ }^{\S}$ and C.J. LIM \\ ${ }^{\S}$ Department of Chemical and Environmental Engineering \\ Faculty of Engineering, Universiti Putra Malaysia \\ 43300 UPM Serdang, Selangor, Malaysia \\ Department of Chemistry, Faculty of Science \\ Universiti Putra Malaysia, 43300 UPM Serdang, Selangor, Malaysia \\ mo5227@yahoo.com
}

Received 19 November 2010; Accepted 19 January 2011

\begin{abstract}
Mixed bacteria from oil palm plantation soil (OPS) were isolated to investigate their ability to utilize glyphosate as carbon source. Results showed that approximately all of the glyphosate was converted to aminomethylphosphonic acid (AMPA) (99.5\%). It is worthy to note that mixed bacteria were able to degrade only $2 \%$ of AMPA to further metabolites. Two bacterial strains i.e. Stenotrophomonas maltophilia and Providencia alcalifaciens were obtained from enrichment culture. Bacterial isolates were cultured individually on glyphosate as a sole carbon source. It was observed that both isolates were able to convert glyphosate to AMPA.
\end{abstract}

Keywords: Pesticide, Glyphosate, Aminomethylphosphonic acid (AMPA), Soil bacteria, Bio-degradation

\section{Introduction}

Pesticides are used as a leading mean to control variety of weed species, harmful insects and approximately 1500 plant diseases. New formulated pesticides are fast acting and they may possess unique action against a specific pest. Herbicides help increasing crop yield by reducing crop losses. In general, pesticides have gone some way to enhance human welfare ${ }^{1}$. On the other hand, serious problems arise due to usage of pesticides. Human pesticide poisonings and illnesses clearly are the highest price being paid for heavy pesticide use. It is estimated that 3 million people are poisoned by pesticides annually and thousands of these cases results in death. Although developing countries use only approximately $20 \%$ of all the pesticides applied in the world most of the pesticide-induced 
deaths occur there. The impact on animals is also considerable. Other impacts of pesticide use include damage to non-target crops, livestock poisonings and destruction of honeybee habitats ${ }^{2}$.

Glyphosate broad-spectrum and nonselective systemic herbicide, is described by the possession of a stable, covalent carbon-to-phosphorus (COP) bond. Glyphosate is utilized extensively for control of plants including grasses, sedges, broad-leaved weeds and woody plants. It can be used on non-cropland as well as on a great variety of crops ${ }^{3}$. In the world, demand for glyphosate has increased substantially. $\mathrm{Ho}^{4}$ reported a 15 -fold increase in usage of glyphosate on major crops between 1994 and 2005. Glyphosate itself is an acid, but it is commonly used in salt form, most commonly the isopropylamine (solubility $12 \mathrm{~g} / \mathrm{L}$ ) salt.

Due to the wide range of used pesticides, it is difficult to produce a single method for the removal of pesticide from water and wastewater. Thus, there are several treatment processes for the removal of pesticides (e.g. biodegradation, photodegradation, oxidation (with air, chlorine, permanganate or ozone), flocculation and filtration, adsorption and membrane techniques). As a general rule, biological treatment is more economical than physicochemical remediation methods as it can be cost-effective and achieve the complete degradation of organic pollutants ${ }^{5}$.

Bacteria are perhaps the most versatile and diversified organisms with regard to their nutritional requirements. Microorganisms are considered to be ubiquitous. For instance, it was estimated that at least 4000 bacterial genome types and up to 40,000 species were in a $\left(100 \mathrm{~cm}^{3}\right)$ sample of forest soil ${ }^{6}$. However, it should be recognized that microorganisms need a long time to obtain the ability to degrade all the new synthetic chemicals introduced into the environment by modem technology. In order to improve and accelerate the removal of target compound exogenous microorganisms are applied to polluted sites or bioreactors. Mixed consortia of microorganisms are more likely able to degrade pollutants completely, compared to partially degradation of pure isolated strains?

Biological treatment employs substantial metabolic capacities of the microorganisms to transform organic pollutants into harmless or, at least, less dangerous compounds. In this method, reasonably, strains acclimatized to polluted site are used to enhance bioremediation process. Thus, several studies were initiated to isolate pure bacterial strains with degrading capability for potential uses in the biological treatment, such as removal of glyphosate from wastewater ${ }^{8}$. Scheme 1 shows the major metabolites and bacterial degradation pathway of glyphosate. Microorganisms can utilize glyphosate as carbon source and leads to production of aminomethylphosphonic acid (AMPA) or as phosphorus source and produces glycine ${ }^{9}$.

The aim of this work was to compare degradation potential of mixed bacteria from activated sludge and oil palm plantation soil for glyphosate. The new isolated strains were tested for ability to utilize glyphosate as the source of carbon.

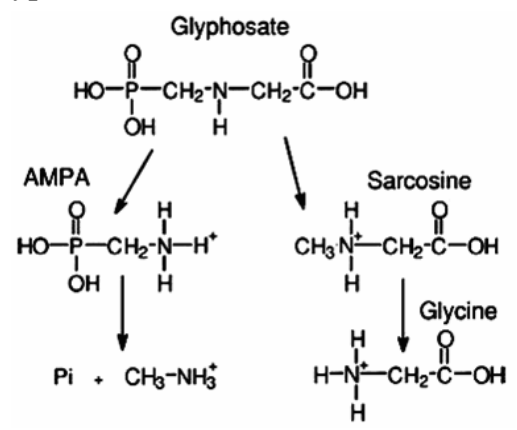

Scheme 1. Pathways and metabolites for bio-degradation of glyphosate 


\section{Experimental}

Glyphosate-contaminated soil was obtained from an oil palm plantation located in Perak, Malaysia. Four soil samples were collected from the surface layer of the soil up to a depth of $30 \mathrm{~cm}$ with samples apart $50 \mathrm{~m}$ covering an area of $250 \mathrm{~m}^{2}$, in an area with more than five years application of glyphosate. Samples were thoroughly mixed and stored at $4{ }^{\circ} \mathrm{C}$.

\section{Enrichment isolation}

Microbial community were isolated from sample by dispersing a sterile-water suspension of soil consisted of basal salts medium: $\mathrm{K}_{2} \mathrm{HPO}_{4}, 5.8 \mathrm{~g} / \mathrm{L} ; \mathrm{KH}_{2} \mathrm{PO}_{4}, 4.5 \mathrm{~g} / \mathrm{L} ;\left(\mathrm{NH}_{4}\right)_{2} \mathrm{SO}_{4}, 2 \mathrm{~g} / \mathrm{L}$; $\mathrm{MgCl}_{2} .2 \mathrm{H}_{2} \mathrm{O}, 0.16 \mathrm{~g} / \mathrm{L} ; \mathrm{CaCl}_{2}, 20 \mathrm{mg} / \mathrm{L} ; \mathrm{NaMoO}_{4}, 2 \mathrm{mg} / \mathrm{L} ; \mathrm{FeSO}_{4} .7 \mathrm{H}_{2} \mathrm{O}, 1 \mathrm{mg} / \mathrm{L} ; \mathrm{MnCl}_{2}$, $1 \mathrm{mg} / \mathrm{L}$ and glyphosate (analytical grade), as the sole carbon source $(300 \mathrm{mg} / \mathrm{L})$. About 1.0 $\mathrm{g}$ of soil was added to separate Erlenmeyer flasks $(250 \mathrm{~mL})$ containing $100 \mathrm{~mL}$ medium. Degradation of glyphosate requires certain microorganism enzymes to participate in the metabolic reaction. These enzymes are generated during the acclimatization process. To initiate the acclimatization the culture was exposed to glyphosate for 30 days then $10 \mathrm{~mL}$ of mixture was transferred into a fresh media. The acclimatization process was repeated three times until mixed bacteria were grown to mid-logarithmic phase at $28{ }^{\circ} \mathrm{C}$ by monitoring the glyphosate concentration. This mixed culture was stored at $4{ }^{\circ} \mathrm{C}$ and used as inoculum for the assays.

\section{Identification of soil bacteria}

In order to identify glyphosate degrading bacteria a sample taken from acclimatized culture was plated on nutrient agar. Agar media was prepared using Difco® Bacto agar. The isolated bacteria were identified by using BIOLOG GEN III (Omnilog, Hayward, CA) according to the manufactures' indications to identify strains. The color density in the microplates wells was interpreted visually as positive, negative. The readings are performed automatically by BIOLOG microlog GEN database to provide identification.

\section{Kinetic of degradation}

Batch kinetics studies were performed to investigate the degradation of glyphosate. Erlenmeyer flasks containing basal salt medium except for glyphosate were autoclaved. The experiments were accomplished in shaking conical flasks with $1000 \mathrm{~mL}$ filter-sterilized Glyphosate solution at a constant temperature of $28^{\circ} \mathrm{C}\left( \pm 2{ }^{\circ} \mathrm{C}\right)$, using incubator instrument at $200 \mathrm{rpm}$. The flasks were prepared with initial inoculum sizes $\left(10^{6}\right.$ organisms $\left.\mathrm{mL}^{-1}\right), \mathrm{pH}$ (6.5), dissolved oxygen (3 mg/L) and glyphosate concentration (300 mg/L). Uninoculated flask with glyphosate containing served as controls.

\section{Quantification of glyphosate}

Glacial acetic acid and trimethyl orthoacetate (TMOA) were obtained from Fluka (Buchs, Switzerland) and ethyl acetate and methanol were of HPLC grade and purchased from J. T. Baker (de Mex., Mexico).

Glyphosate and AMPA were derivatized with TMOA in the presence of acetic acid and the single-step derivatization procedure encompasses the simultaneous esterification of hydroxyl and carboxylic groups and the acetylation of amino groups of herbicides and their major metabolites. The derivatization reaction with acetic acid/TMOA showed some advantages, such as low toxicity, insignificant influence of moisture content in sample upon derivatization reaction and low reaction temperature $\left(<100{ }^{\circ} \mathrm{C}\right)$, over the traditional derivatization methods for GC analysis. 
Gas chromatographic analyses were performed using an Agilent 6890 quadrupole gas chromatograph (Palo Alto, CA, USA) equipped with an Agilent 5975B mass spectrometer (MS). A $30 \mathrm{~m} \times 0.25 \mathrm{~mm}$ HP-5MS fused-silica capillary column with a film thickness of $0.25 \mu \mathrm{m}$ obtained from Agilent. Helium (purity $\geq 99.999 \%$ ) was used as a carrier gas at a flow rate of $0.6 \mathrm{~mL} / \mathrm{min}$. A $1 \mu \mathrm{L}$ extract was injected in a splitless mode at an injection temperature of $250{ }^{\circ} \mathrm{C}$. The oven temperature was programmed to increase from an initial temperature of $100{ }^{\circ} \mathrm{C}$ (held for $3 \mathrm{~min}$ ) to $300{ }^{\circ} \mathrm{C}$ (held for $3 \mathrm{~min})$ at $20^{\circ} \mathrm{C} / \mathrm{min}$. The temperatures of the quadrupole, ion source, and massselective detector interface were 150,230 and $280^{\circ} \mathrm{C}$, respectively. The GC-MS system was operated in the selected-ion monitoring (SIM) mode with the electron multiplier tune value. The electron multiplier voltage for AMPA was set to $200 \mathrm{~V}$ relative to the tune value.

All samples were passed through $0.4 \mu \mathrm{m}$ filter. Bacteria-free sample $(<10 \mu \mathrm{g})$ was dried in a rotary evaporator at temperature $55^{\circ} \mathrm{C}$. The dried sample was mixed with $0.7 \mathrm{~mL}$ of glacial acetic acid and $1.5 \mathrm{~mL}$ of TMOA in a vortex mixer, followed by sonication for $5 \mathrm{~min}$. Derivatization was carried out at $85{ }^{\circ} \mathrm{C}$ for $90 \mathrm{~min}$. After cooling, the reaction solution was taken to complete dryness under a gentle stream of nitrogen. The reaction solution was dried for an additional $5 \mathrm{~min}$ after apparent dryness to ensure the complete removal of excess reagents. Subsequently, the dried derivatives were dissolved in $1.0 \mathrm{~mL}$ of ethyl acetate and injected on GC-MS.

\section{Results and Discussion}

\section{Strain isolation and identification}

A total of 2 bacterial isolates were isolated and identified from oil palm plantation soil (OPS). Identified strains obtained from Biolog GEN III are listed in Table 1. Carbon source and chemical sensitivity, assayed using Micro Plate 94 phenotypic tests, are presented in Table 2.

Table 1. Identification of degrading bacteria for glyphosate

\begin{tabular}{lcc}
\hline \multicolumn{1}{c}{ Species } & Organism type & Probability \\
\hline Stenotrophomonas maltophilia & GN-Nent & 0.81 \\
Providencia alcalifaciens & GN-Nent & 1.0 \\
\hline
\end{tabular}

Figure 1 represents the percentage of glyphosate removal by mixed bacteria from OPS. It is observed that the removal of glyphosate begins without significant lag phase. First metabolite of glyphosate degradation, aminomethylphosphonic acid (AMPMA), appears as glyphosate degrades. Almost, all glyphosate was converted to AMPA during the process while only 2 percent of AMPA was degraded. Although bacteria utilize AMPA to provide phosphorus for their growth, generally, the degradation rate of APMA is lower than glyphosate and the percentage of AMPA removal is dependent on phosphorus requirement of bacteria. AMPA is mineralized ${ }^{10}$ to $\mathrm{PO}_{4}{ }^{3-}$ via equation 1 . These findings of the current study are consistent with those of McAuliffe et al. ${ }^{11}$ who found strain agrobacterium radiobacter transformed the glyphosate to AMPA in the presence of inorganic phosphate and degraded approximately $4 \%$ of the AMPA to further metabolites. Strain flavobacterium sp. was also able to utilize APMA as a sole phosphorus source. It was observed that the presence of $\mathrm{PO}_{4}{ }^{3-}$ did not influence the degradation of glyphosate to AMPA but inhibited further metabolism of AMPA to $\mathrm{PO}_{4}{ }^{3-}$ ion ${ }^{12}$.

$$
\begin{aligned}
& \mathrm{H}_{2} \mathrm{O}_{3} \mathrm{PCH}_{2} \mathrm{NH}_{2}+2 \mathrm{O}_{2} \rightarrow \mathrm{PO}_{4}{ }^{3-}+\mathrm{NH}_{4}+\mathrm{CO}_{2}+\mathrm{H}_{2} \mathrm{O} \\
& \text { (AMPA) }
\end{aligned}
$$


Table 2. Characteristics of the two glyphosate-utilizing isolates

\begin{tabular}{|c|c|c|}
\hline Species Source & $\begin{array}{l}\text { Stenotrophomonas } \\
\text { maltophilia }\end{array}$ & $\begin{array}{l}\text { Providencia } \\
\text { alcalifaciens }\end{array}$ \\
\hline Dextrin & $\bullet$ & - \\
\hline Sucrose & o & 0 \\
\hline$\alpha$-D-Lactose & o & 0 \\
\hline $\mathrm{N}$-Acethyl-Neuraminic Acid & o & o \\
\hline$\alpha$-D-Glucose & $\bullet$ & - \\
\hline D-Fructose & - & - \\
\hline D-Galactose & - & 0 \\
\hline Glycerol & o & D \\
\hline Pectin & 0 & - \\
\hline D-Lactic Acid Methyl & 0 & - \\
\hline Citric Acid & - & - \\
\hline Acetoacetic Acid & $\bullet$ & $\bullet$ \\
\hline Proponic Acid & $\bullet$ & $\bullet$ \\
\hline Acetic Acid & - & - \\
\hline Formic Acid & o & - \\
\hline $4 \% \mathrm{NaCl}$ & - & 0 \\
\hline $8 \% \mathrm{NaCl}$ & 0 & 0 \\
\hline pH 8 & - & - \\
\hline pH 5 & 口 & - \\
\hline
\end{tabular}

\section{Comparison of degrading bacteria from OPS and activated sludge}

Activated sludge was shown to possess degrading bacteria for transforming glyphosate to AMPA ${ }^{13}$. On the other hand there are few bacteria reported to utilize glyphosate as a carbon source. Figure 1 represents the percentage of glyphosate removal by OPS and activated sludge bacteria. A comparison of two results reveals that both mixed bacteria from OPS and activated sludge were able to convert almost all glyphosate to AMPA $(99.5 \%)$ but mixed bacteria from activated sludge had slightly longer lag phase for growth on glyphosate. The shorter lag phase for the growth of OPS bacteria can be attributed to indigenous bacteria with previous exposure to the glyphosate. Acclimatization occurs due to the previous exposure of bacteria to the polluted soil by glyphosate. Singh et al. ${ }^{14}$ acclimatized bacteria by exposing the culture to $p$-cresol for the period of two months. The acclimatized bacteria possess needed enzymes to degrade target compounds ${ }^{15}$. For instance, other research on biodegradation of herbicide 2,4-dichlorophenoxyacetic acid using mixed bacteria with previous exposure to pollution reported a reduction of approximately 40 days in lag phase period ${ }^{16}$.

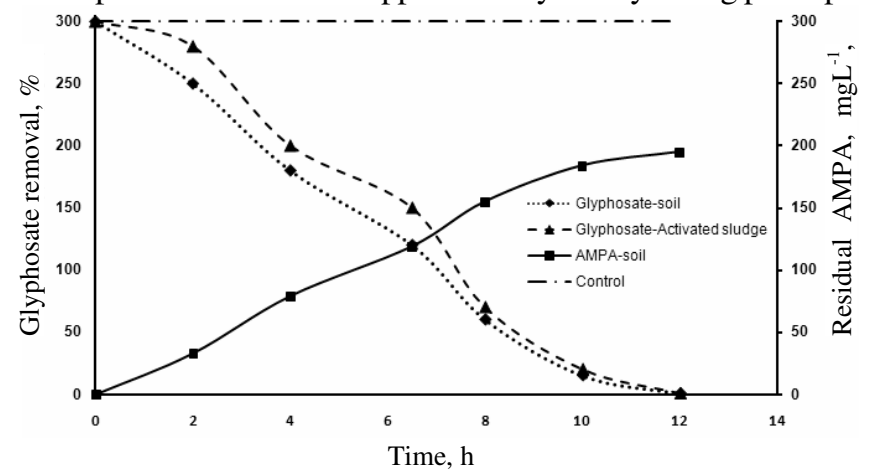

Figure 1. Concentration of glyphosate and AMPA in the basal salt media during biodegradation process, using bacteria from oil palm plantation soil and activated sludge 


\section{Strain isolation and glyphosate degradation}

To evaluate glyphosate-degrading activity, isolated bacteria from OPS acclimatized culture were grown individually on prepared media in shaking Erlenmeyer including $300 \mathrm{mg} / \mathrm{L}$ glyphosate as the source of carbon. Two of these isolates i.e. Stenotrophomonas maltophilia and Providencia alcalifaciens were found to possess the ability to utilize glyphosate in liquid culture. Amorós et al. ${ }^{17}$ reported that the strain Stenotrophomonas maltofilia grew on media including roundup ${ }^{\circledR}$ without any glyphosate removal. It was probably due to the presence of other components except for active ingredient (glyphosate) as a carbon source. There is not a report for the conversion of glyphosate to AMPA by strain Providencia alcalifaciens.

\section{Conclusion}

The conversion of herbicide glyphosate to aminomethylphosphonic acid (AMPA) in water by using mixed bacteria from oil palm plantation soil (OPS) was investigated. The results of this study showed that mixed bacteria were able to transform $99.5 \%$ of glyphosate to its main metabolite AMPA. It was observed that small amount of AMPA (2\%) were degraded to further metabolites. Mixed bacteria from OPS grew on glyphosate as the source of carbon with shorter lag phase compared to mixed bacteria from activated sludge. Three bacterial strains were isolated from enrichment solution and were evaluated individually for their ability to utilize glayphosate as a sole carbon source.

\section{Acknowledgment}

The authors gratefully acknowledge Crop Protection Company for providing the glyphosate throughout this research study.

\section{Reference}

1. Ware G and Whitacre D, The pesticide book, $6^{\text {th }}$ Ed., A Meister Publication, Ohio, 2004.

2. The World Health Report, Reducing Risks Promoting Healthy Life WHO, Geneva, 2002.

3. Petit V, Cabridenc R, Swannell R P J and Sokhi R S, Environ Inter., 1995, 21(2), 167-176.

4. Ho M W, Science in Society, 2008, 40, 4-8.

5. Ang E L, Zhao H and Obbard J P, Enzyme and Microbial Technology, 2005, 37(5), 487-496.

6. Leckie S E, Forest Ecol Manage., 2005, 220, 88-106.

7. Chen B Y and Chang J Sh, J Chin Inst Chem Eng., 2007, 38(3-4), 259-266.

8. $\quad$ Bazot S and Lebeau T, Appl Microbiol Biotechnol., 2008, 77, 1351-1358.

9. Solomon K R, Anadón A, Carrasquilla G, Cerdeira A L, Marshall J and Sanin L H, Rev Environ Contam Toxicol., 2007, 190, 43-125.

10. Jacob G S, Garbow J R, Hallas L E, Kimack N M, Kishore G M and Schaefer J, Strain LBr Appl Environ Microbiol., 1988, 54(12), 2953-2958.

11. McAuliffe K S, Hallas L E and Kulpa C F, J Indian Microbiol., 1990, 6, 219-221.

12. Balthazor T M and Hallas L E, Appl Environ Microbiol., 1986, 51(2), 432-434.

13. Hallas L E, Adams W J and Heitkamp M A, Appl Environ Microbiol., 1992, 58(4), 1215-1219.

14. Singh R K, Kumar S, Kumar S and Kumar A, Biochem Eng J., 2008, 40, 293-303.

15. Nnamchi C I, Obeta J A N and Ezeogu L I, Int J Enviorn Sci Tech., 2006, 3(2), 181-190.

16. Celis E, Elefsiniotis P and Singhal N, Water Res., 2008, 42(12), 3218 - 3224.

17. Amorós I, Alonso J L, Romaguera S and Carrasco J M, Chemosphere, 2007, 67(11), 2221-2228. 


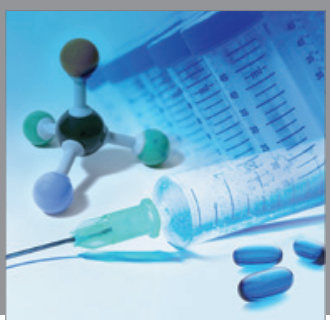

International Journal of

Medicinal Chemistry

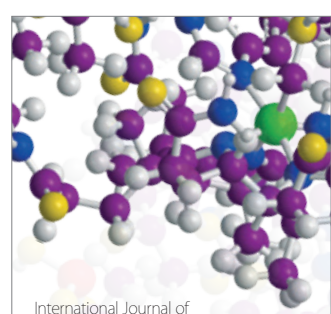

Carbohydrate Chemistry

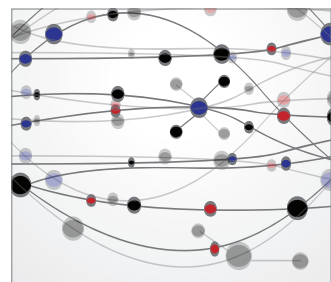

The Scientific World Journal
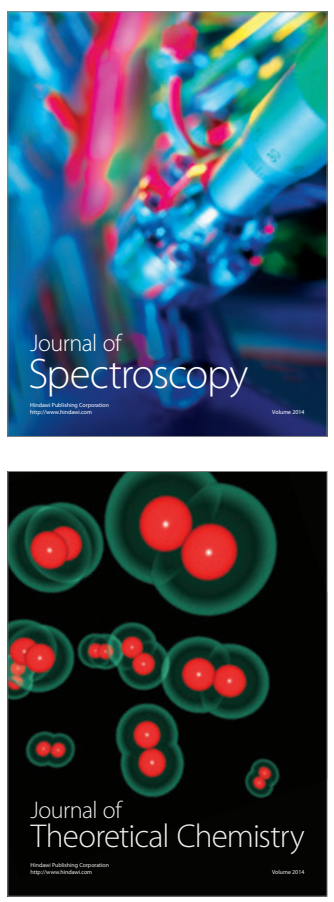
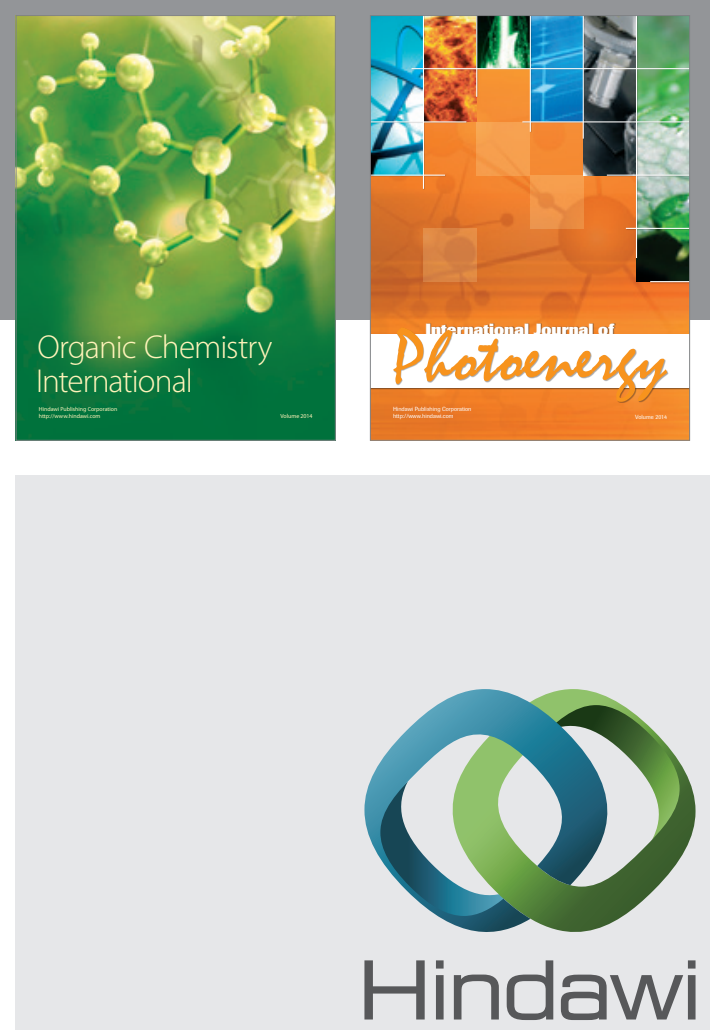

Submit your manuscripts at

http://www.hindawi.com
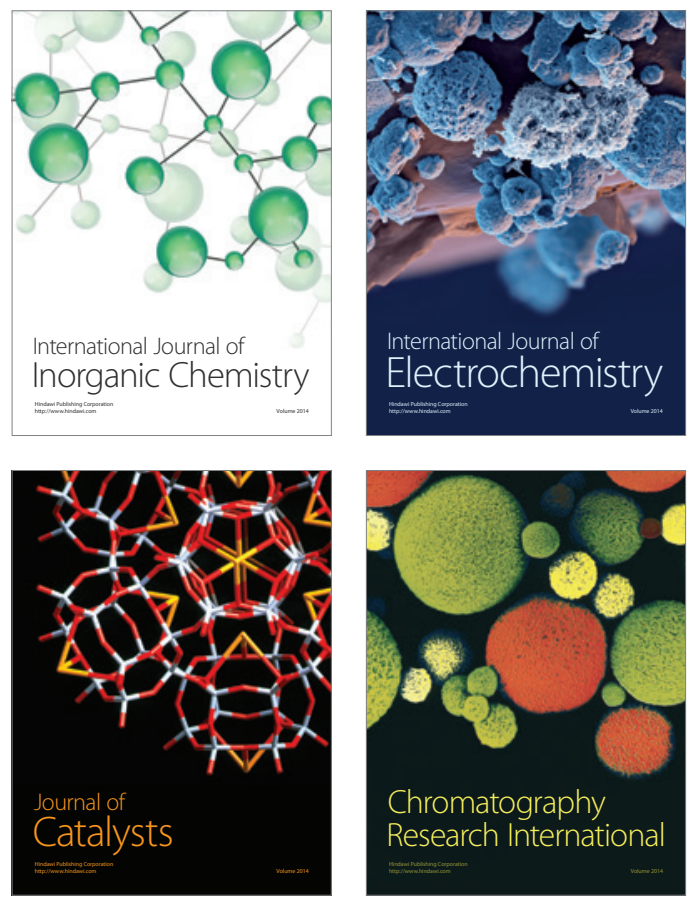
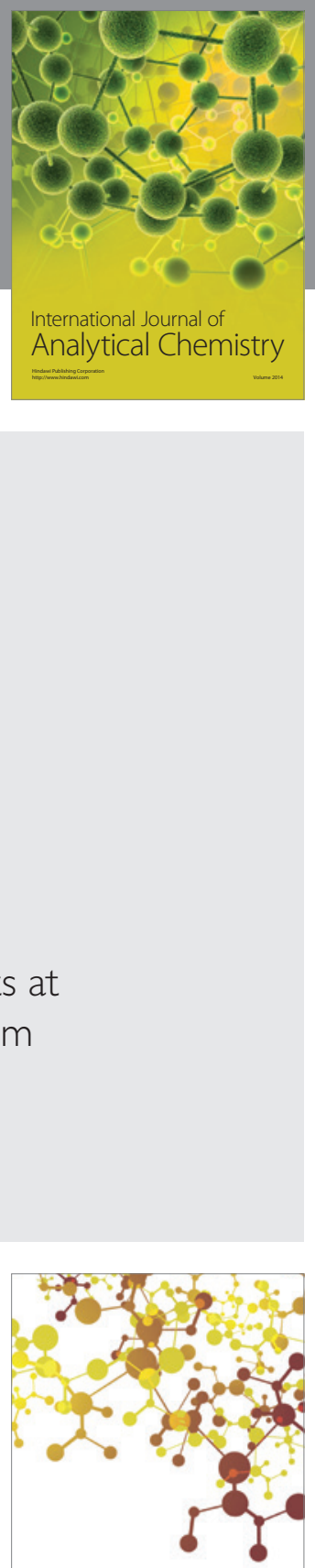

Journal of

Applied Chemistry
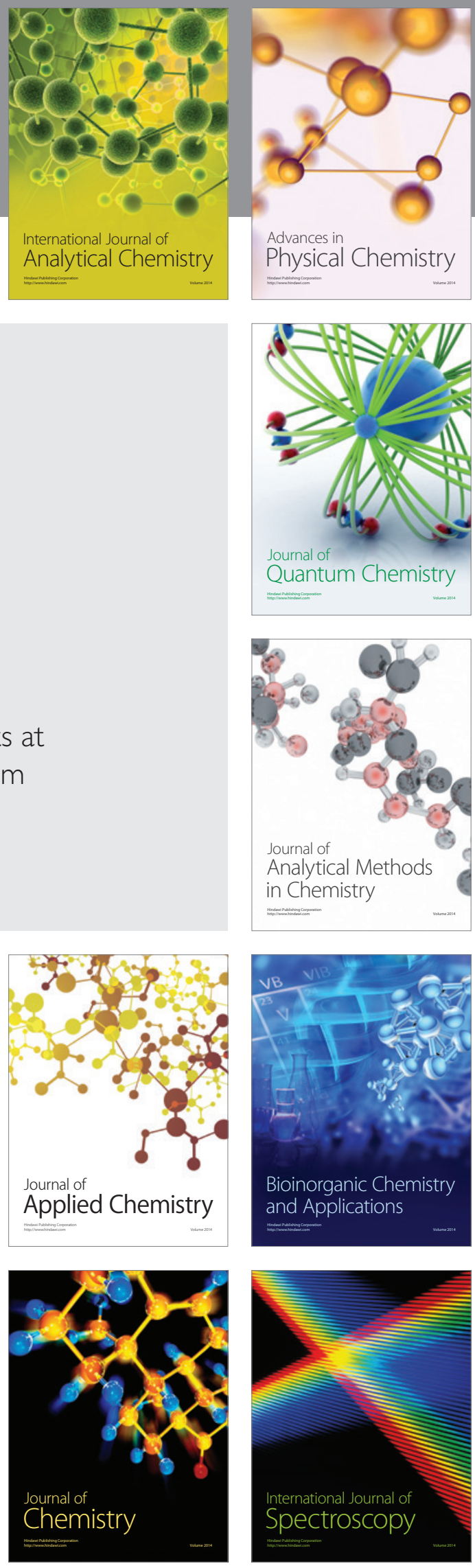